\title{
Effects of intravenous magnesium in suspected acute myocardial infarction: overview of randomised trials
}

\author{
Koon K Teo, Salim Yusuf, Rory Collins, Peter H Held, Richard Peto
}

\begin{abstract}
Objective-To investigate the effect of intravenous magnesium on mortality in suspected acute myocardial infarction.

Design-Systematic overview of all available randomised trials in which patients were allocated to receive either intravenous magnesium or otherwise similar treatment without magnesium.
\end{abstract}

Setting-Coronary care units of several hospitals. Patients - 1301 patients in seven randomised trials.

Main outcome measure-Short term mortality.

Results-Considering the seven trials collectively there were $25(3.8 \%)$ deaths among 657 patients allocated to receive magnesium and $53(8 \cdot 2 \%)$ deaths among 644 patients allocated control, generally during hospital follow up. This represents a 55\% reduction in the odds of death $(p<0.001)$ with $95 \%$ confidence intervals ranging from about one third to about two thirds. 70 of 648 patients allocated magnesium compared with 109 of 641 controls had serious ventricular arrhythmias, suggesting that magnesium reduces the incidence, though the definition varied among trials. Other adverse effects were rare in the limited number of patients for whom this data were available.

Conclusion-Despite the limited number of patients randomised this overview suggests that intravenous magnesium therapy may reduce mortality in patients with acute myocardial infarction. Further large scale trials to confirm (or refute) these findings are desirable.

Clinical Trials Branch, Division of Epidemiology and Clinical Applications, National Heart, Lung, and Blood Institute, Bethesda, Maryland, USA

Koon K Teo, MB, guest researcher

Salim Yusuf, MRCP, scientific project officer

Peter H Held, MD, visiting scientist

\section{Clinical Trials Service}

Unit, University of Oxford, Oxford

Rory Collins, $\mathrm{MB}$, British

Heart Foundation senior

lecturer

Richard Peto, FRS, reader in cancer studies

Correspondence to:

Dr Yusuf.

BMf 1991;303:1499-503

\section{Introduction}

The relevance of magnesium to both the incidence and the management of ischaemic heart disease is not well understood. Geographical comparisons of entire regions indicate that death rates from ischaemic heart disease tend to be higher where magnesium concentrations in soil and water are low, ${ }^{1}$ and case-control studies indicate that magnesium concentrations tend to be lower, and calcium concentrations higher, in those who die of ischaemic heart disease than in those who die of other causes. ${ }^{2}$

Several actions of the magnesium ion could contribute towards some cardioprotective effects. ${ }^{3}$ Low concentrations of magnesium in laboratory animals seem to potentiate catecholamine induced myocardial necrosis. ${ }^{4}$ This may be partly due to the increased coronary artery tone and the increased response to vascoconstrictors (such as angiotensin, serotonin, noradrenaline, and potassium) that is associated with reduced extracellular magnesium concentrations. ${ }^{5}$ Early after the onset of myocardial ischaemia, infusion of magnesium might limit the progression of ischaemic to infarcted myocardium and reduce the risk of arrhythmias being induced by raised local concentra- tions of catecholamines. Increasing serum magnesium concentrations might also limit damage by inhibiting calcium influx into myocardial cells ${ }^{67}$ or by reducing peripheral resistance, or both. ${ }^{8}$ The antiplatelet effects of magnesium ${ }^{9}$ may also have a role in preventing propagation of coronary artery thrombus and reocclusion of the infarct related coronary artery after spontaneous or fibrinolytic induced recanalisation. It is not clear, however, that platelet function would be further inhibited by magnesium in the presence of aspirin, which is now routinely used in acute myocardial infarction. ${ }^{10}$

Magnesium has been shown to limit infarct size in dogs, ${ }^{11}$ and infusions of magnesium have also been shown in animal studies to increase the threshold for electrical excitation of myocardial cells, ${ }^{12}$ thereby reducing the likelihood that an injury current will create an abnormal focus of excitation near the ischaemic or infarcted tissue. Patients with low magnesium concentrations who have acute myocardial infarction or congestive heart failure more commonly have ventricular arrhythmias, ${ }^{1314}$ and magnesium seems to be effective in the treatment of torsades de pointes ${ }^{15} 16$ and of some arrhythmias that are refractory to conventional antiarrhythmic treatment. ${ }^{17} \mathrm{Mag}$ nesium infusions in acute myocardial infarction have therefore been suggested to prevent serious arrhythmias during the day or two after infarction, when serum magnesium concentrations tend to fall ${ }^{18}$ and patients are at a particular risk of ventricular fibrillation.

The need for properly randomised evidence on whether arrhythmias and related mortality can be reduced by magnesium has been reinforced by recent doubts about the safety of some other antiarrhythmic drugs. In some countries (including the United States ${ }^{19}$ but not Britain $^{10}$ ) prophylactic lignocaine was commonly used in acute myocardial infarction to prevent ventricular arrhythmias. Recently, however, two independent overviews of the randomised trials involving over 9000 patients have indicated that prophylactic lignocaine may be associated with an increase in total mortality. ${ }^{2021}$ These concerns have been reinforced by the results of the cardiac arrhythmia suppression trial, ${ }^{22}$ indicating increased mortality with the use of encainide and flecainide in patients with previous myocardial infarction. In addition, an overview of the trials of other class I antiarrhythmic agents shows no benefit when used routinely after myocardial infarction. ${ }^{23}$ Future trials of antiarrhythmic drugs must determine clearly whether there are reductions not just in arrhythmias but in mortality.

The known contraindications to magnesium infusions are few and the treatment regimens are simple and apparently safe. Several randomised controlled trials of intravenous magnesium in suspected acute myocardial infarction have now been conducted..$^{2434}$ We conducted an overview of their results. These trials 
have each included only a few dozen or a few hundred patients and their results are therefore subject to substantial chance fluctuations. However, when taken together more reliable conclusions (that are less subject to biases or to random errors) can be drawn..$^{356}$

\section{Methods \\ SELECTION OF TRIALS AND ACQUISITION OF DATA}

We conducted a search to obtain data on mortality for all randomised patients in all completed, published or unpublished, unconfounded trials of intravenous magnesium in suspected acute myocardial infarction. We scanned the literature by formal computer aided searches, by examining the reference lists of relevant papers, and by asking other investigators about other published or unpublished trials. We excluded controlled trials in which investigators could determine the treatment allocation before deciding whether to enter the patients (for example, trials with allocation that was alternate or based on odds or even dates, or trials with retrospectively determined "historical" controls) even if they were described as randomised, as such methods may introduce bias into allocating treatment and so obscure or exaggerate treatment effects. When the data collected did not include mortality for some randomised patients (for example, patients excluded from analysis because of the failure to confirm the diagnosis of acute myocardial infarction), this information was sought by correspondence ${ }^{3+}$ with the investigators

TABLE I - Design of trials evaluating intravenous magnesium in suspected acute myocardial infarction

\begin{tabular}{|c|c|c|c|c|}
\hline \multirow[b]{2}{*}{ Trial } & \multirow[b]{2}{*}{$\begin{array}{l}\text { Time treatment } \\
\text { started }\end{array}$} & \multicolumn{2}{|c|}{ No of randomised patients } & \multirow[b]{2}{*}{ Exclusion criteria } \\
\hline & & $\begin{array}{l}\text { With } \\
\text { follow up }\end{array}$ & $\begin{array}{l}\text { Without } \\
\text { follow up }\end{array}$ & \\
\hline Morton et $\mathrm{al}^{2+26}$ & $<8 \mathrm{~h}$ after pain & 76 & 5 & $\begin{array}{l}>70 \text { years; Killip class III-IV; } 2 \text { nd-3rd } \\
\text { degree atrioventricular block }\end{array}$ \\
\hline Rasmussen et al ${ }^{27 \%}$ & $<3 \mathrm{~h}$ after admission & 270 & 3 & $\begin{array}{l}\text { Creatinine }>300 \mu \mathrm{mol} / 1 ; 2 \text { nd-3rd degree } \\
\text { atrioventricular block; insulin } \\
\text { dependent diabetes }\end{array}$ \\
\hline Smith et al $l^{19}$ & $<1 \mathrm{~h}$ after admission & 400 & 0 & $\begin{array}{l}\text { Creatinine }>300 \mu \mathrm{mol} / \mathrm{l} ; \text { 3rd degree } \\
\text { atrioventricular block }\end{array}$ \\
\hline Abraham et $a l^{30}$ & Soon after admission & 94 & $\begin{array}{l}\text { ?Few without } \\
\text { confirmed } \\
\text { myocardial } \\
\text { infarction }\end{array}$ & $\begin{array}{l}\text { Systolic blood pressure } \leqslant 90 \mathrm{~mm} \mathrm{Hg} \text {; } \\
\text { cardiac shock; advanced } \\
\text { atrioventricular block }\end{array}$ \\
\hline Feldstedt et $a l^{3+32}$ & $<8 \mathrm{~h}$ after pain & 298 & $? 2$ & $\begin{array}{l}\text { Sinoatrial block, } 2 \text { nd-3rd degree } \\
\text { atrioventricular block; systolic blood } \\
\text { pressure } \leqslant 80 \mathrm{~mm} \mathrm{Hg} \text {; creatinine }>300 \\
\text { mmol/l; insulin dependent diabetes }\end{array}$ \\
\hline Shechter $e t a l^{33}$ & Soon after admission & 115 & 0 & $\begin{array}{l}\text { Cardiogenic shock; bundle branch block; } \\
\text { advanced atrioventricular block }\end{array}$ \\
\hline Ceremuzynski et al & $<12 \mathrm{~h}$ after pain & 48 & 0 & $\begin{array}{l}\text { Pulmonary oedema; cardiogenic shock; } \\
\text { systolic blood pressure } \leqslant 100 \mathrm{~mm} \mathrm{Hg} \text {; } \\
\text { advanced atrioventricular block }\end{array}$ \\
\hline
\end{tabular}

All trials were double blind except that of Ceremuzynski et al, which was single blind. so that intention to treat analysis could be conducted. $262931 \cdot 3$

\section{STATISTICAL METHODS}

The statistical methods used to analyse the results from these trials have been described previously ${ }^{37}$ and a detailed description of the relation between medical common sense and the principles and practice of trial overviews may be found in the recent report of the Early Breast Cancer Trialists' Collaborative Group. ${ }^{39}$ The fundamental principle is that patients allocated to active treatment in one trial should be compared directly only with those allocated to control in the same trial and not with patients in any other trial. For each trial the number of events observed $(\mathrm{O})$ in the treated group is contrasted with the number that would have been expected (E) if treatment had no effect. If treatment was beneficial the observed minus expected value would tend to be negative (and approximately equal to half the number of deaths prevented by treatment ${ }^{38}$ ). Although in any one trial this favourable tendency might be obscured by chance, it should stand out more clearly when the grand total of all the values from the individual trials is examined.

Formal statistical tests of whether treatment is without effect require calculation of $z$, the number of standard deviations by which the grand total of the observed minus expected values differs from zero and comparison of $\mathrm{z}$ with tables of the normal distribution (for example, $z=-1.96$ suggests a two sided $p$ value of about 0.05 in favour of treatment).

Assessment of treatment effects from the combined data assumes that information is available from all, or from an unbiased sample of all, randomised trials, without important bias due to the unavailability of data from unpromising trials or from patients withdrawn after randomisation. It does not, however, assume that the real effects of treatments are the same size in different trials, but merely that any real effects will tend to be in the same direction. An estimate of the "typical" ratio of the odds of dying among patients allocated magnesium with that among controls is given by the formula $\mathrm{e}^{((\mathrm{O}-\mathrm{E}) / \mathrm{V})}$ with an approximate $95 \%$ confidence interval estimated by the formula $\mathrm{e}^{((\mathrm{O}-\mathrm{E}) / \mathrm{V} \pm 1 \cdot 96 / \mathrm{SD})}$, where $\mathrm{V}$ is the variance and $\mathrm{SD}$ the square root of $\mathrm{V} .{ }^{38}$ Odds ratios less than 1.0 indicate protection.

Tests for heterogeneity of treatment effects between trials can be performed, but in practice such heterogeneity tests are of limited value, partly because they are so insensitive to any real differences that may exist but chiefly because some heterogeneity will almost

\begin{tabular}{|c|c|c|c|c|c|c|c|c|}
\hline \multirow[b]{3}{*}{ Trial } & \multirow[b]{3}{*}{$\begin{array}{l}\text { Magnesium } \\
\text { salt }\end{array}$} & \multirow[b]{3}{*}{$\begin{array}{l}\text { Total magnesium } \\
\text { administered }\end{array}$} & \multirow[b]{3}{*}{ Infusion rate } & \multirow[b]{3}{*}{$\begin{array}{l}\text { Duration of } \\
\text { treatment }(\mathrm{h})\end{array}$} & \multicolumn{4}{|c|}{ Mean (SE) serum magnesium $(\mathrm{mmol}) / \mathrm{l})$} \\
\hline & & & & & \multicolumn{2}{|c|}{ Before treatment } & \multicolumn{2}{|c|}{ After treatment } \\
\hline & & & & & $\begin{array}{l}\text { Magnesium } \\
\text { group }\end{array}$ & $\begin{array}{l}\text { Control } \\
\text { group }\end{array}$ & $\begin{array}{l}\text { Magnesium } \\
\text { group }\end{array}$ & $\begin{array}{l}\text { Control } \\
\text { group }\end{array}$ \\
\hline Morton et al $l^{2+2 n}$ & $\mathrm{MgSO}_{4}$ & $\begin{array}{l}1 \cdot 125 \mathrm{mmol} / \mathrm{kg} \\
\quad(90 \mathrm{mmol} / 80 \mathrm{~kg})\end{array}$ & $\begin{array}{l}0.03125 \mathrm{mmol} / \mathrm{kg} / \mathrm{h} \\
(2.5 \mathrm{mmol} / \mathrm{h} / 80 \mathrm{~kg})\end{array}$ & 36 & $0.9+$ & $0 \cdot 8+$ & $1 \cdot 4 \ddagger$ & $0 \cdot 8+$ \\
\hline Rasmussen $e$ t al $:$ : & $\mathrm{MgCl}_{2}$ & $62 \mathrm{mmol}$ & $\begin{array}{l}5.0 \mathrm{mmol} / \mathrm{h} \text { for } 6 \mathrm{hrs} \\
1.1 \mathrm{mmol} / \mathrm{h} \text { for } 18 \mathrm{hrs} \\
0.5 \mathrm{mmol} / \mathrm{h} \text { for } 24 \mathrm{hrs}\end{array}$ & 48 & $0 \cdot 75 \ddagger$ & $0 \cdot 77 \ddagger$ & $1 \cdot 23 \ddagger^{\star \star}$ & $0 \cdot 72 \ddagger$ \\
\hline Smith et al ${ }^{4}$ & $\mathrm{MgSO}_{4}$ & $65 \mathrm{mmol}$ & $2.71 \mathrm{mmol} / \mathrm{h}$ & 24 & $0.80(0.01) \lessgtr$ & $0 \cdot 80(0 \cdot 01) \subseteq$ & $1.51(0.03) \S^{\star}$ & $0.80(0.01) \uparrow$ \\
\hline Abraham et al & $\mathrm{MgSO}_{4}$ & $30 \mathrm{mmol}$ & $\begin{array}{l}10 \mathrm{mmol} \text { over } 20 \mathrm{~min} \\
\text { repeated on } 3 \text { days }\end{array}$ & 48 & $0.92(0.02)$ & $0.91(0.01)$ & $1.07(0.02)$ & $0.90(0.01)$ \\
\hline Feldstedt $e t a l^{4: 2}$ & $\mathrm{MgCl}_{2}$ & $80 \mathrm{mmol}$ & $\begin{array}{l}40 \mathrm{mmol} \text { for } 8 \mathrm{~h} \\
40 \mathrm{mmol} \text { for } 16 \mathrm{~h}\end{array}$ & 24 & & $0 \cdot 839$ & $1 \cdot 52-1 \cdot 62 \mathrm{tt}$ & $0 \cdot 81-0 \cdot 84 \ddagger \ddagger$ \\
\hline Shechter $e t a l^{1+}$ & $\mathrm{MgSO}_{4}$ & $88 \mathrm{mmol}$ & $\begin{array}{l}8.0 \mathrm{mmol} / \mathrm{h} \text { for } 3 \mathrm{~h} \\
1.9 \mathrm{mmol} / \mathrm{h} \text { for } 21 \mathrm{~h} \\
1.0 \mathrm{mmol} / \mathrm{h} \text { for } 24 \mathrm{~h}\end{array}$ & 48 & $\mathrm{NA}$ & NA & NA & NA \\
\hline Ceremuzynski et $a l^{4}$ & $\mathrm{MgSO}_{4}$ & $32 \mathrm{mmol}$ & $1.33 \mathrm{mmol} / \mathrm{h}$ & 24 & $0.76(0.03)$ & $0 \cdot 77(0 \cdot 03)$ & $1 \cdot 00(0 \cdot 03)$ & $0 \cdot 76(0 \cdot 04)$ \\
\hline
\end{tabular}


TABLE III-Mortality in randomised trials of intravenous magnesium in suspected acute myocardial infarction

\begin{tabular}{|c|c|c|c|c|c|c|}
\hline \multirow[b]{3}{*}{ Trial } & \multirow[b]{3}{*}{$\begin{array}{l}\text { Follow up } \\
\text { duration }\end{array}$} & \multirow{2}{*}{\multicolumn{2}{|c|}{$\begin{array}{c}\text { Basic data } \\
\text { (No dead/No followed up) }\end{array}$}} & \multicolumn{3}{|c|}{ Statistical calculations for magnesium group only } \\
\hline & & & & \multirow{2}{*}{$\begin{array}{l}\text { Observed minus } \\
\text { expected deaths } \\
\quad(\mathrm{O}-\mathrm{E})\end{array}$} & \multirow[b]{2}{*}{$\begin{array}{l}\text { Variance of } \\
(\mathrm{O}-\mathrm{E})\end{array}$} & \multirow[b]{2}{*}{ Significance } \\
\hline & & $\begin{array}{l}\text { Magnesium } \\
\text { group }\end{array}$ & $\begin{array}{l}\text { Control } \\
\text { group }\end{array}$ & & & \\
\hline Morton et al $l^{2+26}$ & Hospital & $1 / 40$ & $2 / 36$ & -0.6 & 0.7 & NS \\
\hline Rasmussen et al ${ }^{12}{ }^{2 \mathrm{~K}}$ & 30 days & $9 / 135$ & $23 / 135$ & $-7 \cdot 0$ & $7 \cdot 1$ & $<0.01$ \\
\hline Smith $e t a l^{49}$ & $24 \mathrm{~h}$ & $2 / 200$ & $7 / 200$ & $-2 \cdot 5$ & $2 \cdot 2$ & NS \\
\hline Abraham et $a l^{30}$ & Hospital & $1 / 48$ & $1 / 46$ & $-0 \cdot 0$ & 0.5 & NS \\
\hline Feldstedt $e t a l^{3132}$ & Hospital & $10 / 150$ & $8 / 148$ & $+0 \cdot 9$ & $4 \cdot 2$ & NS \\
\hline Shechter $e a^{3}{ }^{33}$ & Hospital & $1 / 59$ & $9 / 56$ & $-4 \cdot 1$ & $2 \cdot 3$ & $<0.01$ \\
\hline Ceremuzynski et $a l^{24}$ & Hospital & $1 / 25$ & $3 / 23$ & $-1 \cdot 1$ & 0.9 & NS \\
\hline Crude total & & $\begin{array}{l}25 / 657 \\
(3 \cdot 8 \%)\end{array}$ & $\begin{array}{l}53 / 644 \\
(8 \cdot 2 \%)\end{array}$ & $-14 \cdot 4$ & $18 \cdot 0$ & $<0 \cdot 001$ \\
\hline
\end{tabular}

certainly exist no matter what a formal test for heterogeneity may indicate. ${ }^{39}$

\section{Results}

\section{DESCRIPTION OF TRIALS}

Seven randomised trials of the effects of intravenous magnesium in suspected acute myocardial infarction were identified, involving 1301 patients (table I). Six trials used double blind methods of randomisation, ${ }^{24-33}$ one trial used a single blind method. ${ }^{34}$ Detailed examination of baseline characteristics found no significant imbalance suggestive of biases in treatment allocation in any trial. No trial that claimed to be randomised was rejected.

Treatment was started soon after admission to hospital, generally within 12 hours of the onset of chest pain. Some studies included in their principal analyses only those patients in whom infarction was confirmed by electrocardiography or enzyme changes occurring after randomisation, but we obtained follow up data, at least on mortality, for $99.4 \%$ of all randomised patients (irrespective of whether or not infarction was confirmed) so that reasonably unbiased intention to treat analyses were possible. All studies excluded patients with advanced atrioventricular block. Additionally, in some studies, patients with elevated serum creatinine concentrations, hypotension (systolic blood pressure $\leqslant 80, \leqslant 90$, or $\leqslant 100 \mathrm{~mm} \mathrm{Hg}$ ), severe cardiac failure, cardiogenic shock, or age $>70$ years were excluded. In other studies, however, such exclusions were not considered necessary.

Magnesium sulphate was infused in five studies and magnesium chloride in the remaining two studies (table II). The total dose infused varied between $30 \mathrm{mmol}$ and about $90 \mathrm{mmol}$ of magnesium dissolved in as little as $100 \mathrm{ml}$ and as much as $2000 \mathrm{ml}$ of isotonic saline or $5 \%$ glucose, with dosage dependent on body weight in one study ${ }^{24-26}$ and fixed in the other six. The duration of the infusions also varied, ranging from 24 to 48 hours, with 20 minute bolus injections given on three successive days instead of an infusion in one study..$^{30}$ All of the studies were placebo controlled.

Six of the seven trials provided some information on serum magnesium concentrations (table II). The mean pretreatment concentrations were $0 \cdot 8-0.9 \mathrm{mmol} / \mathrm{l}$ and were similar among patients allocated magnesium and those allocated placebo. After randomisation the mean serum concentrations differed by about 0.5 (range 0.2 to 0.7 ) $\mathrm{mmol} / \mathrm{l}$ between treatment and control groups. This difference was largely or wholly due to an increase in serum magnesium in the treatment group, as there was little change among the controls.

\section{OVERALL EFFECT ON MORTALITY}

In general, data on mortality were available for almost all randomised patients until they were discharged from hospital. In one study, ${ }^{29}$ however, only those deaths occurring during the first 24 hours after randomisation were available despite correspondence with the investigators, while in another study "shortterm" follow up included all deaths in the first month. ${ }^{27}{ }^{28}$ In six of the seven studies mortality was lower in the magnesium treated group than in the control group, and these differences were significant $(\mathrm{p}<0.01)$ in two of these studies (table III)..$^{2733} \mathrm{c}$ Overall, the difference in mortality between the 657 patients allocated magnesium and the 644 controls was highly significant: 25 deaths $(3.8 \%)$ versus 53 deaths 0 $(8 \cdot 2 \%), p<0 \cdot 001$. Typically in these trials the odds of death was reduced by about one half, with $95 \% \frac{\text { क }}{2}$ confidence intervals for this difference running from $\mathbb{\Phi}$ about one third to about two thirds (figure). A test for heterogeneity between the various trial results was not significant $\left(\chi^{2}=7 \cdot 6, \mathrm{df}=6, \mathrm{p}>0 \cdot 1\right)$. The study by. Rasmussen et $a l^{27} 28$ contributes substantially to the $\overrightarrow{\vec{\omega}}$ effect on mortality, but the apparent reductions in mortality in this trial $(63 \%(\mathrm{SD} 24) ; \mathrm{p}<0.01)$ and in all $\frac{0}{3}$ other trials combined $(49 \%(22) ; \mathrm{p}=0.03)$ are both significantly different from zero and are not significantly different from each other.

After correspondence with the investigators early mortality data were unavailable for eight patients from $\sigma$ two trials, who were not followed up because infarction was not confirmed. Such patients generally have a low 8 mortality so their exclusion is not likely to have biased 음 our results. Furthermore, consideration of those trials in which all patients were followed up produces similar results $(49 \%(23)$ reduction in odds; $\mathrm{p}<0.03)$ to those seen overall. Separate analysis of the six trials that were double blind also indicates a reduction in mortality similar to the overall results $(64 \%$ (17) reduction in odds, $\mathrm{z}=3 \cdot 2, \mathrm{p}<0.001)$.

Data on longer term mortality are available from only two studies. One year mortality in the study by Rasmussen et al was $20 \%$ in the magnesium group compared with $32 \%$ in the placebo group $(\mathrm{p}<0.02) .{ }^{27} 28$ In that study the difference in mortality developed during the first month $(7 \% v 17 \%, \mathrm{p}<0.01)$, with little further divergence during the remainder of the first year $(15 \% v 18 \%$; NS). In the other study that provides data on deaths after discharge no difference in mortality was observed either early or late, with 22 deaths among patients allocated magnesium and 24 among the controls after a median follow up of about 8 months. ${ }^{31} 32$

SERIOUS MORBIDITY AND POSSIBLE ADVERSE EFFECTS

Information on the development of serious ventricu-

Trials analysed

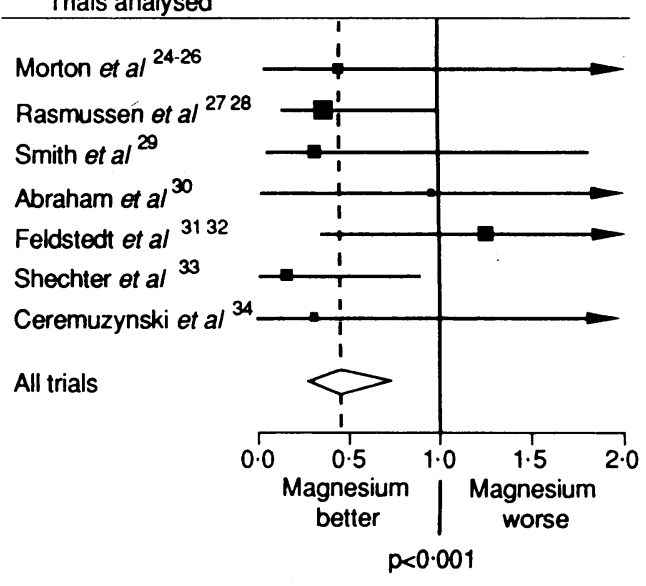

Odds ratios (magnesium:control) for mortality in patients with suspected acute myocardial infarction. $\mathbf{\square}=$ Odds ratio and $99 \%$

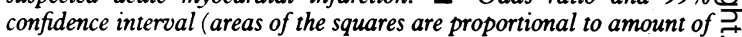
information contributed by trial), $\diamond=95 \%$ confidence interval for the overview. Vertical solid line denotes no difference in mortality between treatment and control, while the vertical broken line denotes a $55 \%$ reduction in the odds of death 
lar arrhythmias was available for all trials (table IV). Ventricular arrhythmias were less common in the magnesium group than in the control group in six of the seven studies, and the difference was significant in two. When all the available information on serious arrhythmias was considered together, there was a significantly lower incidence $(\mathrm{p}<0.001)$ among patients allocated magnesium. The definitions of serious arrhythmias differed among the trials, so some potential for bias exists in the assessment of the effects of magnesium as the type of arrhythmia chosen for emphasis in the trial might have been influenced by the observed results. Limitation of infarct size was studied systematically in only one study, ${ }^{24-26}$ where infarct size (as estimated by concentrations of the MB isomer of creatine kinase) was smaller, though not significantly so, in the magnesium group. Another study found that fewer patients allocated magnesium had infarction confirmed, ${ }^{27} 28$ but this difference was only marginally significant $(p=0.04)$ and was not supported by the available data from other trials.

Possible serious adverse effects of magnesium, such as conduction disturbances or heart failure, were not always systematically looked for. Data on the development of heart failure were available from five of the seven trials (table V). However, the definitions used in the trials varied and the numbers of events were small. Although there were no apparent increases (or decreases) among patients allocated magnesium compared with controls, the data are too limited and too incomplete to do more than suggest that magnesium is not associated with any large excesses. Intravenous magnesium produced flushing in some patients, ${ }^{30}$ and hypotension was reported, ${ }^{30}$ but these effects rarely (if ever) required discontinuation of the magnesium infusion.

\section{Discussion}

This overview of seven randomised controlled trials of intravenous magnesium in 1301 patients with suspected acute myocardial infarction indicates that, in patients at relatively high risk, treatment reduces mortality during the first few weeks by between one third and two thirds. If real, this is a substantial benefit as intravenous magnesium is likely to be suitable for almost all patients with suspected myocardial infarction, the drug costs are small, there are few contraindications, and serious side effects are rare. Magnesium could be used widely not only in developed countries but in countries with limited medical resources. Even if magnesium infusions could reduce mortality by only one quarter (that is, somewhat less than is suggested even by the lower limit of the $95 \%$ confidence interval for this overview) this would be of considerable public health importance worldwide, avoiding tens of thousands of deaths annually.

The general judgment that underlies this approach to the trials of intravenous magnesium is that, although different infusion regimens or different recognisable categories of patient in these trials may have different sized risk reductions, it is less likely that the direction of any effects will be different. This means that an overview of their findings makes good medical sense. (It also makes good statistical sense as biases due to selective emphasis on particular studies need to be avoided.) Even collectively, the total number of deaths available for inclusion in the overview was small ( 25 in the magnesium group $v 53$ in the control group) so withdrawal of some randomised patients or unavailability of trials with less favourable results could, in principle, change the results. For short term mortality such biases are likely to be only small as the net effect is large (over three standard deviations); mortality by allocated treatment is available for almost all randomised patients (although it is not clear whether the reported durations of follow up in the trials were prospectively determined or were influenced by the results); and few, if any, completed trials of substantial size are likely to have been overlooked.

For the effects of treatment of serious ventricular arrhythmias, although some data are available on almost all patients and the apparent risk reduction is large, the decision about what type of arrhythmias to

TABLE IV - Arrhythmias in randomised trials of intravenous magnesium in suspected acute myocardial infarction

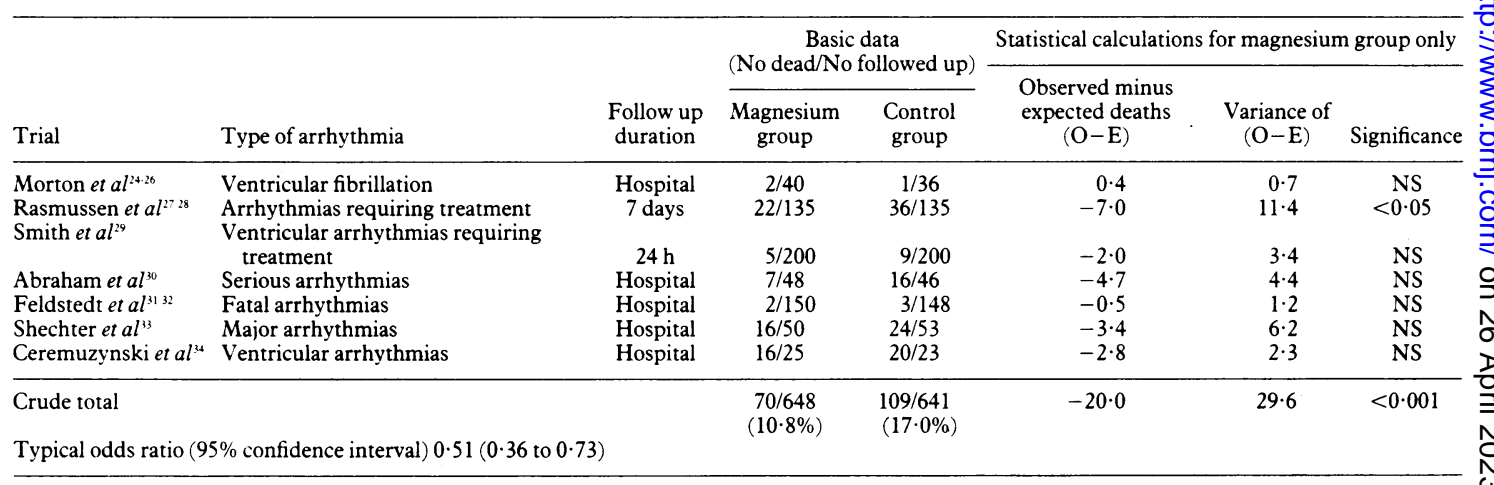

TABLE V-Cardiac failure in randomised trials of intravenous magnesium in suspected acute myocardial infarction

\begin{tabular}{|c|c|c|c|c|c|c|c|}
\hline \multirow[b]{2}{*}{ Trial } & \multirow[b]{2}{*}{ Definition of cardiac failure } & \multirow[b]{2}{*}{$\begin{array}{l}\text { Follow up } \\
\text { duration }\end{array}$} & \multicolumn{2}{|c|}{$\begin{array}{c}\text { Basic data } \\
\text { (No dead/No followed up) }\end{array}$} & \multicolumn{3}{|c|}{ Statistical calculations for magnesium group only } \\
\hline & & & $\begin{array}{l}\text { Magnesium } \\
\text { group }\end{array}$ & $\begin{array}{l}\text { Control } \\
\text { group }\end{array}$ & $\begin{array}{l}\text { Observed minus } \\
\text { expected deaths } \\
\quad(\mathrm{O}-\mathrm{E})\end{array}$ & $\begin{array}{l}\text { Variance of } \\
(\mathrm{O}-\mathrm{E})\end{array}$ & Significance \\
\hline Morton et $a l^{2+26}$ & Killip class III (pulmonary oedema) & $48 \mathrm{~h}$ & $1 / 40$ & $2 / 36$ & $-0 \cdot 6$ & 0.7 & NS \\
\hline Rasmussen et al 7278 & Fatal cardiac failure & 4 weeks & $1 / 56$ & $8 / 74$ & $-2 \cdot 9$ & $2 \cdot 1$ & $<0.05$ \\
\hline Smith et al ${ }^{19}$ & NA & $24 \mathrm{~h}$ & NA & NA & $\mathrm{NA}$ & NA & \\
\hline Abraham et $a l^{3}$ & Cardiogenic shock & Hospital & $1 / 48$ & $2 / 46$ & -0.5 & 0.7 & NS \\
\hline Feldstedt $e t a l^{313 z}$ & Fatal cardiac failure & Hospital & $7 / 150$ & $5 / 148$ & $+1 \cdot 0$ & $2 \cdot 9$ & NS \\
\hline Shechter $e^{a} a^{33}$ & Clinical cardiac failure & Hospital & $13 / 50$ & $15 / 53$ & -0.6 & $5 \cdot 1$ & NS \\
\hline Ceremuzynski et $a l^{34}$ & $\mathrm{NA}$ & Hospital & NA & NA & NA & NA & \\
\hline Crude total & & & $\begin{array}{l}23 / 344 \\
(6 \cdot 7 \%)\end{array}$ & $\begin{array}{l}32 / 357 \\
(9 \cdot 0 \%)\end{array}$ & $-3 \cdot 6$ & $11 \cdot 5$ & $>0.05$ \\
\hline
\end{tabular}

Typical odds ratio ( $95 \%$ confidence interval) $0.73(0.41$ to 1.30$)$

$\mathrm{NA}=\mathrm{Not}$ available 
emphasise in the trials might have been influenced by the observed pattern of results. Substantial biases in our arrhythmia analyses cannot, therefore, be ruled out. Bias is more likely for other measures of serious morbidity as such events were not prospectively defined and were not generally available either from the published reports or even, by correspondence, from the investigators.

\section{IMPLICATIONS FOR CLINICAL PRACTICE AND RESEARCH}

Our study provides strong evidence that intravenous magnesium may have a beneficial effect on mortality. The mortality results of most of the seven small trials, included in the overview are not separately persuasive although the results on arrythmias are more conclusive. ${ }^{27-34}$ In the absence of data from large trials of intravenous magnesium, however, it may be most prudent to be guided by our overall results rather than by undue emphasis on any of the small studies. Larger trials are being conducted (the second Leicester intravenous magnesium intervention trial: LIMIT $-2^{40}$ ) and planned (ISIS-4), and these should help to determine the safety and efficacy of adding intravenous magnesium to current regimens including other effective treatments such as intravenous $\beta$ blockers, ${ }^{41}$ intravenous fibrinolytic treatment, ${ }^{42}$ and oral antiplatelet treatment. ${ }^{42}$ Some smaller studies are also needed to investigate the mechanisms by which magnesium may exert any beneficial effects and to help devise simple but effective magnesium regimens that could have widespread applicability.

We thank Professor D Barnett, Dr L Ceremuzynski, Dr M Feldstedt, Dr K Skagen, Dr M Shechter, Dr B Morton, and Dr K Woods for additional details on their studies, and we would be grateful for information on any other randomised trials of intravenous magnesium in suspected acute myocardial infarction or unstable angina, published or not, that may have been completed and overlooked or that are still recruiting patients. We thank Ms Zola Hall, Isabelle McAndry, and Gale Mead for typing several drafts of this paper.

I Leary WP, Reyes AJ, Lockett CJ, Arbuckle DD, Van der Ryl K. Magnesium and deaths ascribed to ischemic heart disease in South Africa. A preliminary report. S Afr Med J 1983;64:775-6.

2 Elwood PC, Sweetnam PM, Beasley WH, Jones D, France R. Magnesium and calcium in the myocardium: cause of death and area differences. Lance 1980;ii:720-2.

3 Woods KL. Possible pharmacological actions of magnesium in acute myocardial infarction. Br f Clin Pharmacol 1991;32:3-10.

4 Mishra RK. Studies on experimental magnesium deficiencies in the albino rat. Functional and morphological changes associated with low intake of $\mathrm{Mg}$. Reviews in Canadian Biology 1960;19:122-35.

5 Turlapaty PDMV, Altura BM. Magnesium deficiency produces spasm of coronary arteries: relationship to aetiology of sudden death in ischemic hear disease. Science 1980;208:198-200.

6 Altura BM, Altura BT. Influence of magnesium on drug induced contraction and ion content in rabbit aorta. Am F Physiol 1971;220:938-44.

7 Turlapaty PD, Altura BM. Extracellular magnesium ions control calcium exchange and content of vascular smooth muscle. Eur $\mathcal{f}$ Pharmacol 1978;52:421-3.

8 Shine KI. Myocardial effects of magnesium. Am f Physiol 1979;237:H413-23.

9 Heptinstall S, Lyne S, Mitchell JRA, Will EJ. Magnesium infusion in acute myocardial infarction Lancet $1986 ; \mathrm{i}: 552$.

10 Collins R, Julian D. British Heart Foundation surveys (1987 and 1989) of United Kingdom treatment policies for acute myocardial infarction. Br Heart f 1991;66:259-64.

11 Chang C, Varghese PJ, Downey J, Bloom S. Magnesium deficiency and myocardial infarct size in the dog. 7 Am Coll Cardiol 1985;5:280-9.

12 Ghani MF, Rabah M. Effect of magnesium chloride on electrical stability of the heart. Am Heart $\mathcal{F}$ 1977;94:600-2.
13 Dyckner T. Serum magnesium in acute myocardial infarction. Relation to arrhythmias. Acta Med Scand 1980;207:59-66.

14 Dyckner T, Wester PO. Ventricular extrasystoles and intracellular electrolyte before and after potassium and magnesium infusions in patients on diuretic reatment. Am Heart 7 1979;97:12-8.

15 Tzivoni D, Banai S, Schuger C, Benhorin J, Keren AA, Gottlieb S, et al. Treatment of torsades de pointes with magnesium sulfate. Circulation 1988;77:393-7.

16 Perticone F, Adinolf L, Bonaduce D. Efficiency of magnesium sulfate in the treatment of torsades de pointes. Am Heart $\mathcal{F}$ 1986;112:847-9.

17 Iseri LT. Magnesium and dysrrhythmias. Magnestum Bulletin 1986;8:223-9.

18 Rasmussen HS, Aurup P, Hoiberg S, Jensen EK, McNair P. Magnesium and acute myocardial infarction: transient hypomagnesemia not induced by renal magnesium loss in patients with acute myocardial infarction. Arch Intern Med 1986;146:872-4.

19 Hlatky MA, Cotugno HE, Mark DB, O'Connor C, Califf RM, Pryor DB Trends in physician management of uncomplicated acute myocardial infarction, 1970 to 1987. Am I Cardiol 1988;61:515-8.

20 MacMahon S, Collins R, Peto R, Koster RW, Yusuf S. Effects of prophylactic lidocaine in suspected acute myocardial infarction. An overview of results from the randomized, controlled trials. IAMA 1988:260:1910-6.

21 Hine KC, Laird N, Hewitt P, Chalmers TC. Meta-analytic evidence agains prophylactic use of lidocaine in acute myocardial infarction. Arch Intern Med 1989;14:2694-8.

22 Cardiac Arrhythmia Suppression Trial (CAST) Investigators. Preliminary report: effect of encainide and flecainide on mortality in a randomized tria of arrhythmia suppression after myocardial infarction. $N$ Engl $\mathcal{F}$ Med 1989;321:406-12.

23 Hine LK, Laird N, Hewitt P, Chalmers TC. Meta-analysis of empirical long term antiarrhythmic therapy after myocardial infarction. fAMA 1989;262: 3037-40.

24 Morton BC, Smith FM, McKibbon TJ, Nair RC, Poznanski WJ. Magnesium therapy in acute myocardial infarction. Magnesium Bulletin 1981;1a:192-4.

25 Morton BC, Smith FM, Nair RC, McKibbon TG, Poznanski WJ. The clinica effects of magnesium sulphate treatment in acute myocardial infarction. Magnesium Bulletin 1984;4:133-6.

26 Morton BC, Nair RC, Smith FM, McKibbon TG, Poznanski WJ. Magnesium therapy in acute myocardial infarction $-\mathrm{a}$ double blind study. Magnesium 1984;3:346-52.

27 Rasmussen HS, McNair P, Norregard P, Backer V, Lindeneg O, Balslov S. Intravenous magnesium in acute myocardial infarction. Lancet 1986;1: 234-6

28 Rasmussen HS, Gronbaek M, Cintin C, Balslov S, Norregard P, McNair P. One-year death rate in 270 patients with suspected acute myocardia infarction, initially treated with intravenous magnesium or placebo. Clin Cardiol 1988;11:377-81.

29 Smith LF, Heagerty AM, Bing RF, Barnett DB. Intravenous infusion of magnesium sulphate after acute myocardial infarction: effects on arrhythmias and mortality. Int $\mathcal{f}$ Cardiol 1986;12:175-80.

30 Abraham AS, Rosenmann D, Kramer M, Balkin J, Zion MM, Farbstien H, et al. Magnesium in the prevention of lethal arrhythmias in acute myocardial infarction. Arch Intern Med 1987;147:753-5.

31 Feldstedt $M$, Bouchelouche $P$, Svenningsen A, Boesgaard S, Brooks I, Aldershvile $\mathrm{J}$, et al. Failing effect of magnesium-substitution in acute myocardial infarction. Eur Heart $f$ 1988;9:226.

32 Feldstedt $M$, Bouchelouche P, Svenningsen A, Boesgaard S, Brooks L, Lech $\mathrm{Y}$, et al. Magnesium substitution in acute ischaemic heart syndromes Eur Hearl $\mathcal{f}$ (in press)

33 Shechter M, Hod H, Marks N, Behar S, Kaplinsky E, Rabinowitz B. Magnesium therapy and mortality in acute myocardial infarction. Am $\mathcal{F}$ Cardiol 1990;66:271-4.

34 Ceremuzynski L, Jurgiel R, Kulakoswski P, Gebalska J. Threatening arrhythmias in acute myocardial infarction are prevented by intravenous magnesium sulfate. Am Heart $\mathcal{F}$ 1989;118:1333-4.

35 Collins R, Gray R, Godwin J, Peto R. Avoidance of large biases and large random errors in the assessment of moderate treatment effects: the need for systematic overviews. Stat Med 1987:6:245-50.

36 Peto R. Why do we need systematic overviews of randomized trials? Stat Med 1987;6:233-40.

37 Yusuf S, Peto R, Lewis J, Collins R, Sleight P. Beta blockade during and after myocardial infarction: an overview of the randomized trials. Prog Cardiovasc Dis 1985;27:335-71.

38 Antiplatelet Trialists' Collaboration. Secondary prevention of vascular disease by prolonged antiplatelet treatment. $B M F$ 1988;296:320-31.

39 Early Breast Cancer Trialists' Collaborative Group. Treatment of early breast cancer. Vol I. Worldwide evidence 1985-1990. Oxford: Oxford University Press, 1990.

40 Magnesium for acute myocardial infarction? [Editorial.] Lancet 1991;338 667-8.

41 ISIS-1 (First International Study of Infarct Survival) Collaborative Group. Randomized trial of intravenous atenolol among 16027 cases of suspected acute myocardial infarction: ISIS-1. Lancet 1986;ii:57-66.

42 ISIS-2 (Second International Study of Infarct Survival) Collaborative Group. Randomized trial of intravenous streptokinase, oral aspirin, both, or neither among 17187 cases of suspected acute myocardial infarction: ISIS-2. Lancet 1988;ii:349-60.

(Accepted 1 October 1991) 